\title{
Genetic diversity of Bursaphelenchus cocophilus in South America
}

\author{
Arinaldo P. SILVA ${ }^{1,4}$, Pedro P. PARrA ${ }^{2}$, Vicente P. CAMPOS ${ }^{1}$, Sara S. Costa ${ }^{1}$, \\ Cláudia S.L. Vicente ${ }^{4,5}$, Letícia G. FerreirA ${ }^{3}$, Ricardo M. SouZA ${ }^{3}$ and Manuel MotA ${ }^{4,6, *}$ \\ ${ }^{1}$ Department of Plant Pathology, Federal University of Lavras, Lavras, MG, Brazil \\ ${ }^{2}$ International Centre for Tropical Agriculture (CIAT), Cali, Colombia \\ ${ }^{3}$ Lab. de Pesquisa em Nematologia, CCTA/LEF, Universidade Estadual \\ do Norte Fluminense Darcy Ribeiro, Rio de Janeiro, Brazil \\ ${ }^{4}$ NemaLab/ICAAM - Instituto de Ciências Agrárias e Ambientais Mediterrânicas \& Departamento \\ de Biologia, Universidade de Évora, Núcleo da Mitra, Ap. 94, 7002-554 Évora, Portugal \\ ${ }^{5}$ Department of Environmental Biology, Chubu University, Kasugai, Japan \\ ${ }^{6}$ Departamento de Ciências da Vida, Universidade Lusófona de Humanidades \\ e Tecnologias, EPCV, C. Grande 376, 1749-024 Lisbon, Portugal
}

Received: 18 November 2015; revised: 2 March 2016 Accepted for publication: 2 March 2016; available online: 5 April 2016

\begin{abstract}
Summary - Molecular characterisation of Bursaphelenchus cocophilus, the causal agent of 'red ring disease', is imperative for efficient identification procedures in Brazil and Colombia, because quarantine species such as B. xylophilus and B. mucronatus are already listed in both countries. ITS-1/2 region and D2-D3 segment of LSU rDNA were used to characterise isolates of B. cocophilus obtained from coconut plantations in Brazil and Colombia. Results from ITS-1/2 and LSU rDNA regions showed that all isolates of B. cocophilus from Brazil and Colombia formed a monophyletic group. The LSU rDNA region indicated that all isolates formed a single monophyletic group with high Bayesian posterior probability (100\%). This is the first study on ITS-1/2 for the characterisation of B. cocophilus populations. A species-specific primer was designed for identification of B. cocophilus.
\end{abstract}

Keywords - Aphelenchoididae, Brazil, coconut palm, Colombia, diagnostics, ITS, LSU, phylogeny, red ring disease, species-specific primers.

Bursaphelenchus Fuchs, 1937, a genus including more than 100 described species worldwide, belongs to the family Aphelenchoididae (Kanzaki \& Giblin-Davis, 2012). The most important species within this genus are the facultative plant-parasitic nematode Bursaphelenchus xylophilus (Steiner \& Buhrer, 1934) Nickle, 1970 responsible for pine wilt disease (PWD) in Pinus spp. forests (Mota \& Vieira, 2008; Vicente et al., 2012), B. sycophilus Kanzaki, Tanaka, Giblin-Davis \& Davies, 2014, a putative plant-parasitic of Ficus variegata (Kanzaki et al., 2014), and B. cocophilus (Cobb, 1919) Baujard, 1989, the causal agent of red ring disease (RRD) in coconut (Cocos nucifera L.), oil palm (Elaeis guineensis Jacq.) and peach palm (Bactris gasipaes Kunth). RRD is of significant economic importance in coconut (losses up to $60 \%$ in plantations) and oil palm industry in Colombia, Brazil and other countries of Latin America (Costa Rica, Ecuador, Mexico, Nicaragua, Panama, Peru, Surinam and Venezuela) (FAO, 2011). Thus, it is imperative for South American countries to be on the alert for quarantine nematode species of Bursaphelenchus such as B. xylophilus as an A1 quarantine pest (EPPO/European Plant Protection Organisation). In addition to B. cocophilus, the only two other Bursaphelenchus species described from Brazil are B. mиcronatus Mamiya \& Enda, 1979, and the mycophagous species B. fungivorus Franklin \& Hooper, 1962 (Oliveira et al., 2011; Pereira et al., 2013). In Trinidad, B. gerberae Giblin-Davis, Kanzaki, Ye, Center \& Thomas, 2006, has been found associated with the American palm weevil (Giblin-Davis et al., 2006).

Considered an obligate parasite, B. cocophilus has not yet been successfully cultivated in vitro, as reported for

* Corresponding author, e-mail: mmota@uevora.pt 
B. sycophilus (Kanzaki et al., 2014). Recently, numerous attempts to grow the nematode on a variety of fungal species, as well as using tissue culture, have failed (R. Souza, pers. comm.). In addition, the host range of this nematode is restricted to the family Arecaceae, parasitising more than 17 species. The life cycle of $B$. cocophilus is completed within 9-10 days (Singh et al., 2013) and time of appearance of external symptoms can vary depending on the host. Bursaphelenchus cocophilus is mainly vectored by the American palm weevil Rhynchophorus palmarum L. (Griffith, 1968), the sugarcane weevil Metamasius sp. (Silva, 1991) and the palm weevil Dynamis borassi (F.) (Gerber et al., 1990). It can also be transmitted through oviposition on healthy plants, faeces or direct contact of roots from a healthy to an infected plant (Araújo, 1990).

The use of molecular techniques for identification of this nematode would potentially increase accuracy of diagnosing infected palms in Brazil and Colombia, thereby avoiding misidentification with other members of Bursaphelenchus not yet present or reported in these countries. In recent years, much work has been done on the molecular characterisation of different Bursaphelenchus species (Burgermeister et al., 2005, 2009; Mota et al., 2006; Ye et al., 2007; Zhang et al., 2008; Li et al., 2009; Cardoso et al., 2012; Valadas et al., 2012, 2013; Marek et al., 2014). Within this genus, the LSU (D2-D3) and the ITS-1/2 ribosomal regions have been targeted for diversity studies (Mota et al., 2006; De Luca et al., 2011; Subbotin et al., 2011; Cardoso et al., 2012; Sultana et al., 2013) and for diagnosis purposes (Burgermeister et al., 2005, 2009). Both regions are used since they provide a valuable tool in the identification of nematodes (PalomaresRius et al., 2010, 2013) and reconstruction of phylogenetic relationships (Kaplan et al., 2000; Ye et al., 2007; Coomans et al., 2012). Although molecular studies for identification of B. xylophilus are abundant (Cao et al., 2005; Zhou et al., 2007; Jung et al., 2010; Cardoso et al., 2012; Valadas et al., 2013; Ye \& Giblin-Davis, 2013), little is known about $B$. cocophilus. To date, only four sequences (SSU, LSU and mtCOI regions) of B. cocophilus collected in Costa Rica (one isolate) and Honduras (one isolate) from coconut and African oil palm are available in the NCBI database (Ye et al., 2007). Molecular characterisation of the LSU rDNA and ITS-1/2 regions of the plant-parasitic nematode $B$. cocophilus from different geographic populations was the main purpose of this study to further explore intraspecific phylogenetic relationships of RRN populations, and design a species-specific primer for rapid identification of $B$. cocophilus.

\section{Materials and methods}

\section{SAMPLE COLLECTION AND NEMATODE EXTRACTION}

In total, 13 coconut plantations were visited in the main producing regions of Brazil and Colombia for sample collection (Table 1). Transverse portions (discs) of infected coconut stems were cut and carried to the laboratory for nematode extraction. Stem fragments of red ring-diseased palms were chopped into small pieces. Both coloured and discoloured red ring-diseased tissues were mixed and $\mathrm{ca}$ $30 \mathrm{~g}$ of tissue per sample was placed in a modified nematode extraction tray with a plastic net and paper tissue. Nematodes were allowed to migrate from tissue into the water overnight. Each nematode suspension was sieved through $20 \mu \mathrm{m}$ pore size sieves, and individually handpicked to Eppendorf tubes with DESS (dimethyl sulphoxide, disodium EDTA, and saturated $\mathrm{NaCl}$ ) preserving solution for DNA extraction and molecular analysis (Yoder et al., 2006).

\section{DNA EXTRACTION}

DNA extraction was done using a PureLink ${ }^{\circledR}$ Genomic DNA extraction kit (Life Technologies, Thermo Fisher Scientific). For each geographic region, 20 nematodes with mixed developmental stages were handpicked and transferred from the DESS solution to deionised water for $1 \mathrm{~h}$ to remove preserving solution. Nematodes were then placed in a cavity slide with $20 \mu \mathrm{l}$ of PureLink ${ }^{\circledR}$ Genomic Digestion Buffer (Life Technologies), and cut using a blade. The remaining steps were followed according to the manufacturer's protocol. DNA samples were quantified in a Nanodrop 2000 , and then stored at $-20^{\circ} \mathrm{C}$ until use.

\section{DNA SEQUENCING}

Amplification of the D2-D3 segment in LSU rDNA was done using the following set of primers: forward D2A (5'-ACAAGTACCGTGAGGGAAAGT-3') and reverse primer D3B (5'-TGCGAAGGAACCAGCTACTA$3^{\prime}$ ) (Nunn, 1992). For amplification of ITS-1/2, the forward F194 (5'-CGTAACAAGGTAGCTGTA-3') (Ferris $e t$ al., 1993) and reverse primer 5368 (5'-TTTCACTCGCC GTTACTAAGG-3') (Vrain, 1993) were used. PCR reaction mixture $(25 \mu \mathrm{l})$ consisted of $2.5 \mu \mathrm{l}$ of $10 \times$ PCR Buffer (Fermentas), $0.5 \mu \mathrm{l}$ of each primer (10 mM), 0.25 
Table 1. Geographic locations and origins of coconut host of Bursaphelenchus cocophilus isolates used in the study.

\begin{tabular}{llll}
\hline Country & State & Collection locations & GenBank accession number \\
\cline { 3 - 4 } & & & D2-D3 \\
\hline Brazil & Pernambuco & Petrolina & KT156771 \\
Brazil & Pernambuco & Petrolina & KT156770 \\
Brazil & Alagoas & Maceió & KT156769 \\
Brazil & Alagoas & Maceió & KT156774 \\
Brazil & Alagoas & Maceió & KT156773 \\
Brazil & Espírito Santo & São Mateus & KT156772 \\
Colombia & Nariño & Aguaclara & KT156778 \\
Colombia & Nariño & Aguaclara & KT156775 \\
Colombia & Nariño & Aguaclara & KT156776 \\
Colombia & Nariño & Tumaco & KT156777 \\
Colombia & Nariño & Tumaco & KT156781 \\
Colombia & Nariño & Tumaco & KT156779 \\
Colombia & Nariño & Tumaco & KT156780 \\
\hline
\end{tabular}

units of Taq DNA polymerase (Fermentas), $2.0 \mu \mathrm{l}$ of $10 \mathrm{mM} \mathrm{MgCl} 2,0.2 \mathrm{mM}$ dNTPs (Fermentas) and $3 \mu \mathrm{l}$ of DNA template ( $c$ a $3-5 \mathrm{ng} / \mu \mathrm{l}$ ). Amplification of the D2D3 segment was done with an initial denaturation step at $95^{\circ} \mathrm{C}$ for $5 \mathrm{~min}$, followed by 35 reaction cycles of $94^{\circ} \mathrm{C}$ for $30 \mathrm{~s}, 55^{\circ} \mathrm{C}$ for $45 \mathrm{~s}$, and $72^{\circ} \mathrm{C}$ for $2 \mathrm{~min}$, with a final extension at $72^{\circ} \mathrm{C}$ for $10 \mathrm{~min}$. ITS-1/2 amplification was done using an initial denaturation step at $94^{\circ} \mathrm{C}$ for $3 \mathrm{~min}$, followed by 40 reaction cycles of $94^{\circ} \mathrm{C}$ for $1 \mathrm{~min}, 48^{\circ} \mathrm{C}$ for $1 \mathrm{~min}$, and $72^{\circ} \mathrm{C}$ for $1 \mathrm{~min}$, with a final extension at $72^{\circ} \mathrm{C}$ for $2 \mathrm{~min}$. PCR products were electrophoresed in a $1 \%$ agarose gel stained with SYBR Safe DNA gel stain (Life Technologies, Thermo Fisher Scientific), followed by purification with Exonuclease I (Exo I, Thermo Scientific) and FastAP (Thermosensitive Alkaline Phosphatase, Thermo Scientific). Purified D2-D3 and ITS-1/2 fragments were quantified and then sequenced by Macrogen.

\section{MoleCUlar PHylogenetics}

Consensus sequences were assembled from forward and reverse sequences using SeqAssem version 07/2008 (SequentiX Digital DNA Processing). Additional sequences of Bursaphelenchus species were retrieved from GenBank (NCBI). Aphelenchoides besseyi (EU325682 and JF826519) was used as outgroup in both analyses. Sequences were aligned by MAFFT version 7.212 (Katoh \& Standley, 2013). Base substitution models in ITS-1/2 and D2-D3 were determined using Kakusan4 (Tanabe, 2011). Bayesian analysis was performed using
MrBayes version 3.2 (Ronquist \& Huelsenbeck, 2003) running, respectively, $2 \times 10^{5}$ (ITS-1/2) and $3.5 \times$ $10^{5}$ (D2-D3) generations and setting the burn in at 25000 (ITS-1/2) and 50000 (D2-D3). Convergence of runs was checked with Tracer version 1.6 (Rambaut \& Drummond, 2007). Estimations of posterior probabilities of the phylogenetic trees (Larget \& Simon, 1999) were determined using the MCMC (Markov chain Monte Carlo) methods in MrBayes. The phylogenetic trees were visualised using FigTree version 1.4.2 (Rambaut, 2008).

All sequences reported in this study were deposited in GenBank under the accession numbers listed in Table 1.

\section{ANALYSIS OF THE GENETIC DISTANCE OF POPULATIONS}

Genetic distances between populations were assessed by comparing the number of pairwise differences, using MEGA 5 (Tamura et al., 2011). Sequences of the D2D3 segment from phylogenetic analysis were used for the analysis of population genetic structure of B. cocophilus.

\section{SPECIES-SPECIFIC PCR FOR THE IDENTIFICATION OF B. COCOPHILUS}

Based on the D2-D3 and ITS-1/2 region alignment, unique regions for $B$. cocophilus were identified and selected for primer design. Primers were designed with PRIMER 3 software (Rozen \& Skaletsky, 1999). NCBI blast was used to compare primers sequences and verify 


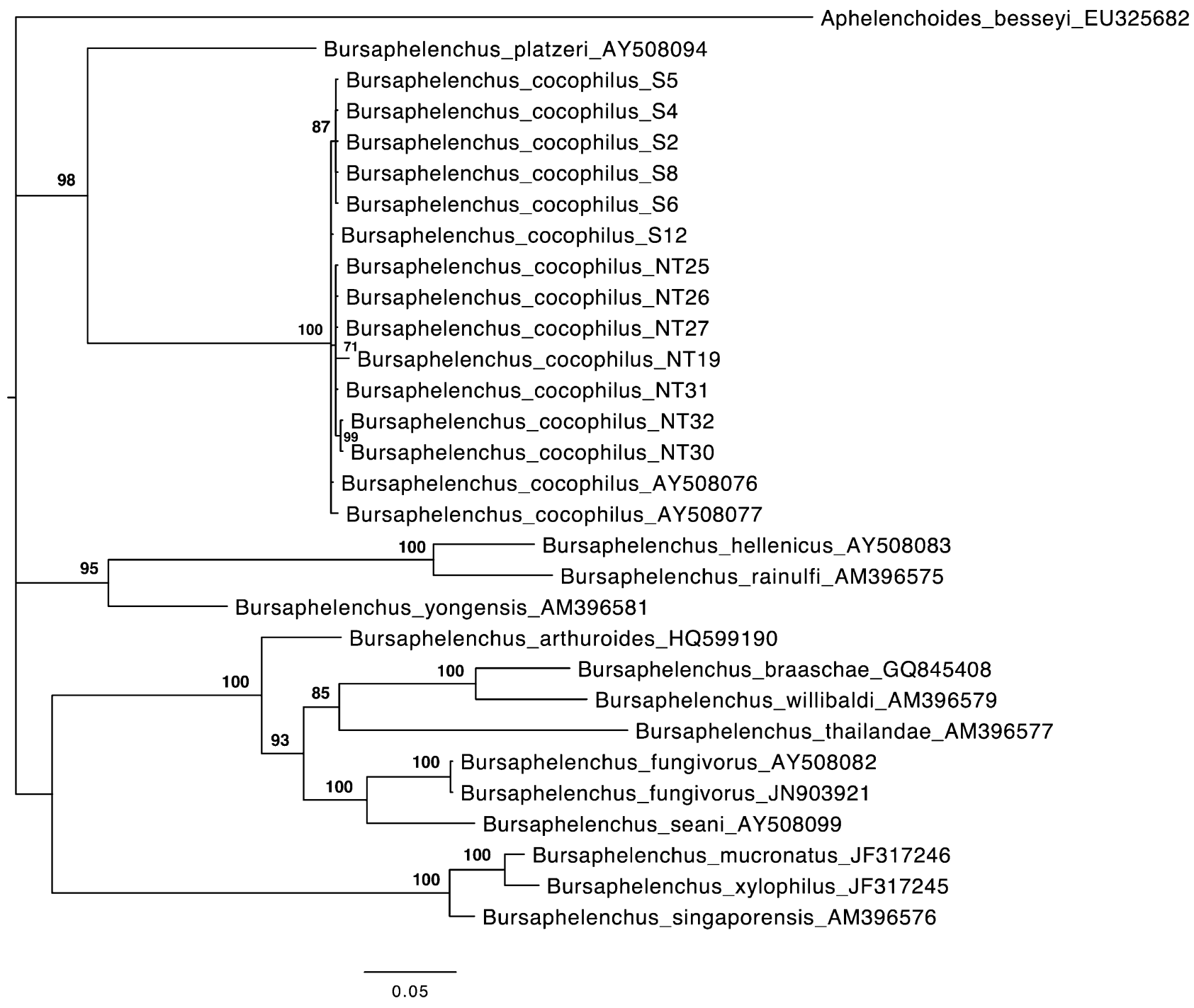

Fig. 1. Phylogenetic tree from Bayesian analysis of the D2-D3 region of 28S of Bursaphelenchus cocophilus and other species of Bursaphelenchus. The best-fit substitution model was estimated using Kakusan4. The HKY85 (Hasegawa et al., 1985) Gamma model $\left(-\ln \mathrm{L}=4434.887 ; \ln \mathrm{Pr}=45.528 ; \mathrm{TL}=2.257 ; \mathrm{r}(\mathrm{A} \leftrightarrow \mathrm{C})=3.9^{-2} ; \mathrm{r}(\mathrm{A} \leftrightarrow \mathrm{G})=0.259 ; \mathrm{r}(\mathrm{A} \leftrightarrow \mathrm{T})=0.115 ; \mathrm{r}(\mathrm{C} \leftrightarrow \mathrm{G})=3.3^{-2}\right.$; $\mathrm{r}(\mathrm{C} \leftrightarrow \mathrm{T})=0.429 ; \mathrm{r}(\mathrm{G} \leftrightarrow \mathrm{T})=0.125)$; $\mathrm{pi}(\mathrm{A})=0.165 ; \mathrm{pi}(\mathrm{C})=0.205 ; \mathrm{pi}(\mathrm{G})=0.342 ; \mathrm{pi}(\mathrm{T})=0.288 ; \alpha=0.426)$ was then used for Bayesian analysis. Bayesian posterior probability values (BPP), exceeding $50 \%$ and given in the appropriate clade, were estimated after $3.5 \times 10^{5}$ generations.

their homology with other previously deposited sequences in GenBank. Designed primers were used in PCR reactions with B. cocophilus, B. xylophilus and B. fungivorus DNA in order to validate specificity of the designed primers. For the ITS- $1 / 2$ forward primer BC1F $\left(5^{\prime}-\mathrm{AA}\right.$ CTACCGTCTTCCGCTGTCG- $\left.3^{\prime}\right)$ and reverse BC1R ( $5^{\prime}$ TTGAGCACCAACACGCCGTCA-3') were used. The PCR reaction $(25 \mu \mathrm{l})$ was performed by using $2.5 \mu \mathrm{l}$ of
PCR Buffer $(10 \times) ; 0.5 \mu 1$ of each primer $(10 \mathrm{mM}) ; 0.25$ units of Taq DNA polymerase; $2.0 \mu \mathrm{l}$ of $\mathrm{MgCl}_{2}(10 \mathrm{mM})$; $0.5 \mu 1$ of dNTPs (mM) and $3 \mu 1$ of DNA template. Amplification was carried out according to the following program: initial denaturation at $92^{\circ} \mathrm{C}$ for $2 \mathrm{~min}, 30$ reaction cycles at $94^{\circ} \mathrm{C}$ for $1 \mathrm{~min}$, annealing $55^{\circ} \mathrm{C}$ for $45 \mathrm{~s}$, extension $72^{\circ} \mathrm{C}$ for $2 \mathrm{~min}$ and a final extension at $72^{\circ} \mathrm{C}$ for 5 min. 


\begin{tabular}{|c|c|}
\hline is $\mathrm{K}$ & 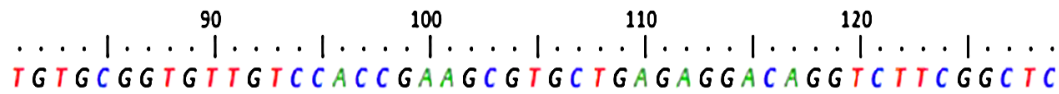 \\
\hline & . \\
\hline & $\ldots \ldots \ldots \ldots \ldots \ldots \ldots \ldots \ldots \ldots$ \\
\hline & $\ldots \ldots$ \\
\hline & 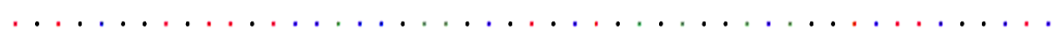 \\
\hline & 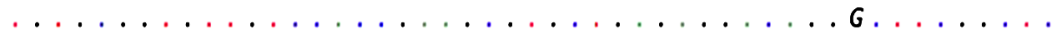 \\
\hline & $\ldots \ldots \ldots \ldots \ldots \ldots \ldots \ldots \ldots \ldots \ldots \ldots \ldots \ldots \ldots \ldots$ \\
\hline & $\ldots \ldots \ldots \ldots \ldots$ \\
\hline & $\ldots \ldots \ldots \ldots \ldots \ldots \ldots \ldots \ldots \ldots \ldots \ldots$ \\
\hline & $\ldots \ldots \ldots \ldots \ldots \ldots \ldots \ldots \ldots$ \\
\hline & $\ldots$. \\
\hline & $\ldots \ldots G$ \\
\hline & $\cdots \cdots$ \\
\hline & $G$ \\
\hline & 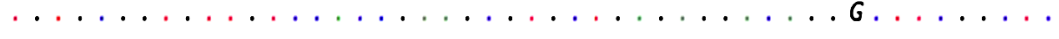 \\
\hline
\end{tabular}

Fig. 2. Alignment of sequences of the D2-D3 region of the 28S gene isolates of Bursaphelenchus cocophilus from Brazil and Colombia showing transition mutation of nucleotide (C-T). This figure is published in colour in the online edition of this journal, which can be accessed via http://booksandjournals.brillonline.com/content/journals/15685411.

Table 2. Genetic distances among Bursaphelenchus cocophilus population based on D2-D3 28Sr RNA gene region sequence data.

\begin{tabular}{|c|c|c|c|c|c|c|c|c|c|c|c|c|c|c|c|}
\hline \multirow{2}{*}{$\begin{array}{l}\text { Accession } \\
\text { number }\end{array}$} & \multicolumn{6}{|c|}{ Brazil } & \multicolumn{7}{|c|}{ Colombia } & \multirow{2}{*}{$\begin{array}{l}\text { Costa } \\
\text { Rica } \\
076\end{array}$} & \multirow{2}{*}{$\begin{array}{c}\text { Honduras } \\
077\end{array}$} \\
\hline & 71 & 70 & 69 & 74 & 73 & 72 & 78 & 75 & 76 & 77 & 81 & 79 & 80 & & \\
\hline KT156771 & - & 0 & 0 & 0 & 0 & 1 & 6 & 2 & 2 & 3 & 4 & 2 & 4 & 1 & 3 \\
\hline KT156770 & 0.000 & - & 0 & 0 & 0 & 1 & 6 & 2 & 2 & 3 & 4 & 2 & 4 & 1 & 3 \\
\hline KT156769 & 0.000 & 0.000 & - & 0 & 0 & 1 & 6 & 2 & 2 & 3 & 4 & 2 & 4 & 1 & 3 \\
\hline KT156774 & 0.000 & 0.000 & 0.000 & - & 0 & 1 & 6 & 2 & 2 & 3 & 4 & 2 & 4 & 1 & 3 \\
\hline KT156773 & 0.000 & 0.000 & 0.000 & 0.000 & - & 1 & 6 & 2 & 2 & 3 & 4 & 2 & 4 & 1 & 3 \\
\hline KT156772 & 0.002 & 0.002 & 0.002 & 0.002 & 0.002 & - & 5 & 1 & 1 & 2 & 3 & 1 & 3 & 0 & 2 \\
\hline KT156778 & 0.010 & 0.010 & 0.010 & 0.010 & 0.010 & 0.008 & - & 1 & 0 & 2 & 3 & 1 & 3 & 2 & 4 \\
\hline KT156775 & 0.003 & 0.003 & 0.003 & 0.003 & 0.003 & 0.002 & 0.006 & - & 0 & 1 & 2 & 0 & 2 & 1 & 3 \\
\hline KT156776 & 0.003 & 0.003 & 0.003 & 0.003 & 0.003 & 0.002 & 0.006 & 0.000 & - & 1 & 2 & 0 & 2 & 1 & 3 \\
\hline KT156777 & 0.005 & 0.005 & 0.005 & 0.005 & 0.005 & 0.003 & 0.008 & 0.002 & 0.002 & - & 1 & 1 & 1 & 2 & 3 \\
\hline KT156781 & 0.006 & 0.006 & 0.006 & 0.006 & 0.006 & 0.005 & 0.010 & 0.003 & 0.003 & 0.002 & - & 1 & 0 & 3 & 5 \\
\hline KT156779 & 0.003 & 0.003 & 0.003 & 0.003 & 0.003 & 0.002 & 0.006 & 0.000 & 0.000 & 0.002 & 0.003 & - & 0 & 1 & 3 \\
\hline KT156780 & 0.006 & 0.006 & 0.006 & 0.006 & 0.006 & 0.005 & 0.010 & 0.003 & 0.003 & 0.002 & 0.000 & 0.003 & - & 3 & 5 \\
\hline AY508076 & 0.002 & 0.002 & 0.002 & 0.002 & 0.002 & 0.000 & 0.008 & 0.002 & 0.002 & 0.003 & 0.005 & 0.002 & 0.005 & - & 2 \\
\hline AY508077 & 0.005 & 0.005 & 0.005 & 0.005 & 0.005 & 0.003 & 0.011 & 0.005 & 0.005 & 0.006 & 0.008 & 0.005 & 0.008 & 0.003 & - \\
\hline
\end{tabular}

* Above diagonal shows the number of different sites and below diagonal genetic distances.

\section{Results}

A total of 13 isolates were used for molecular characterisation of B. cocophilus collected in Brazil and Colombia. The phylogenetic analyses of the D2-D3 segment of rDNA LSU sequences, using Bayesian analysis and a comprehensive data set of species within Bursaphelenchus showed that populations from Brazil, Colombia and Costa Rica and Honduras (B. cocophilus AY508076 and
AY508077) formed a single clade with high Bayesian posterior probability $(100 \%)$ and distinct from other species (Fig. 1). The genetic diversity analysis of the D2-D3 segment of LSU revealed that Brazilian isolates are identical except for isolate KT156772 which had a single nucleotide substitution (T) (Fig. 2). The Colombian populations display more diversity (Table 2), isolate KT156778 having the highest number of substituted nucleotides. 


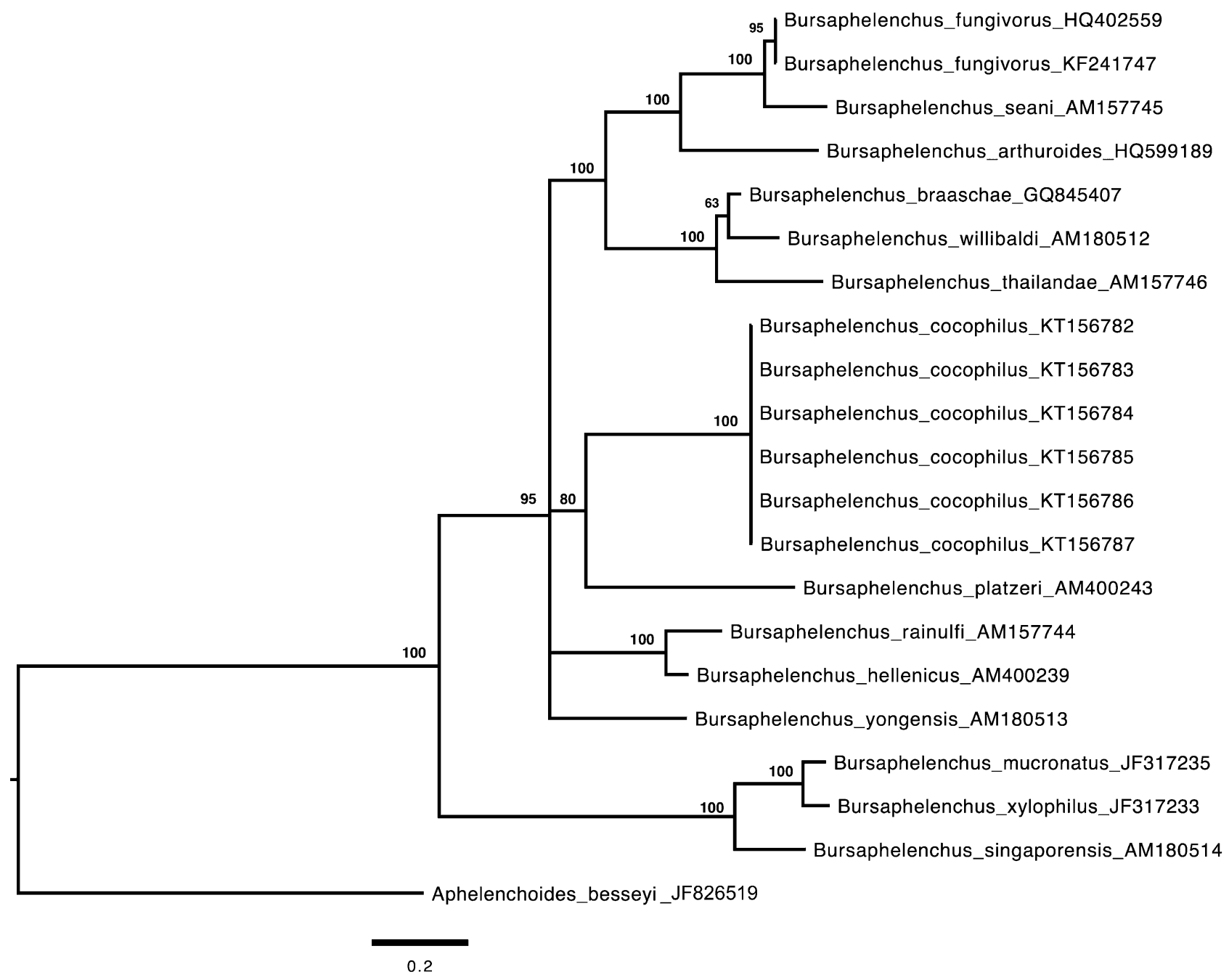

Fig. 3. Phylogenetic tree from Bayesian analysis of the ITS-1/2 region of Bursaphelenchus cocophilus and other species of Bursaphelenchus. The best-fit substitution model was estimated using Kakusan4. The GTR (Generalised time-reversible) Gamma model $(-\ln \mathrm{L}=5804.434 ;-\ln \operatorname{Pr}=12.575 ; \mathrm{TL}=5.352 ; \operatorname{kappa}=3.621 ; \operatorname{pi}(\mathrm{A})=0.214 ; \operatorname{pi}(\mathrm{C})=0.192 ; \operatorname{pi}(\mathrm{G})=0.252 ; \operatorname{pi}(\mathrm{T})=$ 0.343; $\alpha=0.461$ ) was then used for Bayesian analysis. Bayesian posterior probability values (BPP), exceeding $50 \%$ and given in the appropriate clade, were estimated after $2 \times 10^{5}$ generations.

Regarding the ITS- $1 / 2$ region, B. cocophilus isolates from Brazil and Colombia formed a single monophyletic group, with $100 \%$ Bayesian posterior probability, and distinct from other species of the Bursaphelenchus (Fig. 3). From the ITS-1/2 alignment of $B$. cocophilus, a specific primer set was designed using sequence differences between other sequences of Bursaphelenchus species. The specific DNA sequence of the B. cocophilus fragment amplified with this primer set showed no similarity to other sequences in GenBank. The $\mathrm{BC} 1 \mathrm{~F}$ and $\mathrm{BC} 1 \mathrm{R}$ primers were able to detect the target species specifically and providing PCR products with the expected size of $528 \mathrm{bp}$ fragment (Fig. 4). Non-specific amplifications did not occur in any of the B. cocophilus isolates, and no amplification was observed for the isolates of $B$. xylophilus.

Based upon the overall topologies of trees, the sister species of $B$. cocophilus was B. platzeri AY508094. Analysis of both regions ITS-1/2 and D2-D3 of LSU rDNA separated B. cocophilus from other species listed in GenBank. 


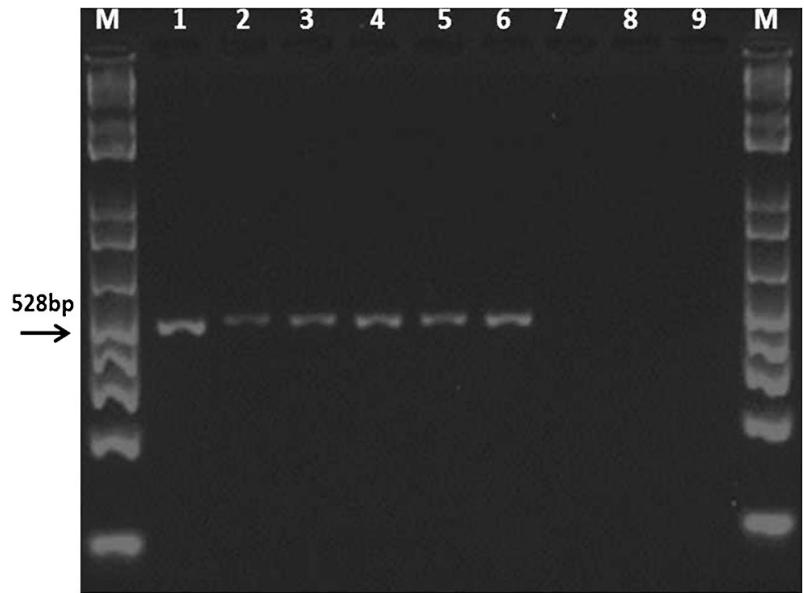

Fig. 4. Amplification of PCR products using $B C 1 F / R$ speciesspecific primers of Bursaphelenchus cocophilus populations. Lane order: Lanes 1-6: KT156771; KT156770; KT156769; KT156774; KT156773; KT156772; Lane 7: B. xylophilus; Lane 8: B. fungivorus; and Lane 9: negative control. Nematode codes are as abbreviated in Table 1. Lane M represents a DNA marker of known molecular weights. The amplicon sizes are indicated by arrows.

\section{Discussion}

Although the ITS-1/2 region did not distinguish B. cocophilus isolates, this region has been used to analyse genetic diversity of worldwide B. xylophilus populations (Canada, China, Japan, Portugal, Russia and the USA), allowing group segregation depending upon country of origin. Also, this region has shown high polymorphism between B. xylophilus and B. mucronatus populations, both inter- and intra-specific (Futai \& Kanzaki, 2002; Cardoso et al., 2012). Likewise, De Luca et al. (2011) reported high variability in populations of Pratylenchus spp. based on this molecular marker. In addition to the ITS-1/2 region, the D2-D3 region of rDNA LSU has also been studied for plant-parasitic nematode taxonomy and species identification (Kaplan et al., 2000; de la Peña et al., 2007; Ye et al., 2007; Múnera Uribe et al., 2010; Mekete et al., 2011; Oliveira et al., 2011). Based on the LSU region, we could clearly distinguish Brazilian and Colombian populations. Comprehensive sequence analysis identified a single nucleotide (T) exchange specific to the Colombian populations and absent in Brazilian, Costa Rica and Honduras populations.

The north-eastern South American coast is considered to be the potential centre of origin of B. cocophilus, where the first palm tree symptomatic of the disease was observed and reported to occur in Trinidad (Cobb, 1919;
Gerber et al., 1990; Giblin-Davis et al., 2013). Our analysis supports low genetic diversity between $B$. cocophilus populations from Brazil and Colombia. The variability of the D2-D3 region and ITS-1/2 for B. cocophilus is in accordance with that observed in $B$. niphades, where more variable sites (nucleotides alteration) were observed in D2-D3 than ITS-1/2, which showed a single-nucleotide alteration (Tanaka et al., 2014). Nevertheless, this region has been useful as a DNA marker to distinguish intra- and inter-specific isolates of B. xylophilus and B. mucronatus because of their high sequence polymorphism (Futai \& Kanzaki, 2002).

Other molecular markers such as $18 \mathrm{~S}$ and COI (data not shown) were attempted but were difficult to amplify with conventional universal primers, as also observed by Ye et al. (2007) for a population from Costa Rica, perhaps because of the low sequence homology at the primer annealing site (Vossen et al., 2014).

Moreover, we also showed that B. cocophilus and $B$. platzeri might have shared a common ancestor, grouping distantly from other mycophagous and plant-parasitic nematode. This last observation corroborates the inferred phylogeny studies of Ye et al. (2007) and Kanzaki et al. (2014).

Nuclear and mitochondrial regions have accumulated mutations over time, some regions being more prone to change than others. The ITS- $1 / 2$ sequence can provide useful genetic markers for species, due to their low intraspecific variation (Gasser, 2001). The ITS-1/2 region was used for the design of species-specific primers in other species of nematodes such as Xiphinema, for conventional PCR (Oliveira et al., 2005) and real-time PCR (Van Ghelder et al., 2015); B. xylophilus nested PCRbased (Takeuchi et al., 2005) and real-time PCR (Cao et al., 2005; Ye \& Giblin-Davis, 2013); Meloidogyne hapla, M. chitwoodi and M. fallax multiplex PCR (Zijlstra, 1997) and Pratylenchus coffeae (Saeki et al., 2003). Until now, B. cocophilus has been identified based only on morphological characters or by using molecular markers $(28 \mathrm{~S}, 18 \mathrm{~S}$ and mtCOI) (Ye et al., 2007).

Accurate and quick detection of this plant-parasitic nematode is very important to prevent the introduction and dispersal of the pest to new sites (Ye \& Giblin-Davis, 2013; Van Ghelder et al., 2015). The design of speciesspecific primers is necessary for $B$. cocophilus, since there are no indisputable morphological diagnostic characters for this species in the described members of the genus. The presence of a precloacal papilla, bursal and vulval 
flap shape, and ratio a are not exclusively diagnostic for B. cocophilus (Giblin-Davis et al., 1989).

The present study focused on the molecular characterisation of $B$. cocophilus populations from Brazil and Colombia using the most informative ribosomal DNA genetic loci currently used for nematode phylogeny (Fouly et al., 1997; Kaplan et al., 2000; De Luca et al., 2011; Subbotin et al., 2011; Marek et al., 2014) and allowing the design of a species-specific primer pair for accurate identification of $B$. cocophilus. Here we characterised the genetic diversity of several B. cocophilus populations from Brazil and Colombia. Knowledge of the intra-specific diversity of $B$. cocophilus will enable a better understanding of ITS-1/2 population dynamics. More studies should be done with a larger number of isolates from different regions of Brazil and from other countries using other genomic loci, thus generating additional information about the genetic/population structure of $B$. cocophilus.

\section{Acknowledgements}

The authors thank the following researchers for their support: José Mauro Castro, Fátima Muniz, Dulce Warwick, José Inácio and Edilberto Sampaio, and also the company Agropalma (Ricardo Tinoco) for helping with sample collection. This work was supported by CAPESPDSE (Proc. 99999.012780/2013-08), FAPEMIG (PhD fellowship to the first author), CNPq, and FEDER Funds through the Operational Programme for Competitiveness Factors - COMPETE and National Funds through FCT Foundation for Science and Technology under the Strategic Project PEst-C/AGR/UI0115/2011 and ICAAM Universidade de Évora. We also are grateful to Dr Robin Giblin-Davis for providing valuable inputs to this paper and his contributions to the research on B. cocophilus in Columbia.

\section{References}

Araújo, J.C. (1990). O anel-vermelho do dendê. Circular Técnica. Manaus, EMBRAPA, 21 pp.

Burgermeister, W., Gu, J. \& Braasch, H. (2005). ITS-RFLP patterns for differentiation of 26 Bursaphelenchus species (Nematoda: Parasitaphelenchidae) and observations on their distribution. Russian Journal of Nematology 13, 29-42.

Burgermeister, W., Braasch, H., Metge, K., Gu, J., Schroder, T. \& Woldt, E. (2009). ITS-RFLP analysis, an efficient tool for differentiation of Bursaphelenchus species. Nematology 11, 649-668
Cao, A.X., Liu, X.Z., Zhu, S.F. \& Lu, B.S. (2005). Detection of the pinewood nematode, Bursaphelenchus xylophilus, using a real-time polymerase chain reaction assay. Phytopathology 95, 566-571.

Cardoso, J.M.S., Fonseca, L. \& Abrantes, I. (2012). Genetic diversity of ITS sequences of Bursaphelenchus xylophilus nematode isolates. Genetics and Molecular Research 11, 4508-4515.

Cobb, N.A. (1919). A newly discovered nematode (Aphelenchus cocophilus, n. sp.), connected with a serious disease of the coco-nut palm. West Indian Bulletin 17, 203-210.

Coomans, A., De Ley, I.T., Jimenez, L.A. \& De Ley, P. (2012). Morphological, molecular characterisation and phylogenetic position of Longidorus mindanaoensis n. sp. (Nematoda: Longidoridae) from a Philippine Avicennia mangrove habitat. Nematology 14, 285-307.

de la Peña, E., Karssen, G. \& Moens, M. (2007). Distribution and diversity of root-lesion nematodes (Pratylenchus spp.) associated with Ammophila arenaria in coastal dunes of Western Europe. Nematology 9, 881-901.

De Luca, F., Reyes, A., Troccoli, A. \& Castillo, P. (2011). Molecular variability and phylogenetic relationships among different species and populations of Pratylenchus (Nematoda: Pratylenchidae) as inferred from the analysis of the ITS rDNA. European Journal of Plant Pathology 130, 415-426.

EPPO - European and Mediterranean Plant Protection Organization (2015). EPPO global database. Available online at https:// gd.eppo.int (accessed 9 January 2016).

FAO (2011). Guide to implementation of phytosanitary standards in forestry. FAO Forestry Paper 164. Rome, Italy, FAO.

Ferris, V., Ferris, J. \& Faghihi, J. (1993). Variations in spacer ribosomal DNA in some cyst forming species of plant parasitic nematodes. Fundamental and Applied Nematology $16,177-184$.

Fouly, H., Wilkinson, H.T. \& Chen, W. (1997). Restriction analysis of internal transcribed spacers and the small subunit gene of ribosomal DNA among four Gaeumannomyces species on JSTOR. Mycologia 89, 590-598.

Futai, K. \& Kanzaki, N. (2002). A PCR primer set for determination of phylogenetic relationships of Bursaphelenchus species within the xylophilus group. Nematology 4, 35-41.

Gasser, R.B. (2001). Identification of parasitic nematodes and study of genetic variability using PCR approaches. In: Kennedy, M. \& Harnett, W. (Eds). Parasitic nematodes: molecular biology, biochemistry, and immunology. Wallingford, UK, CABI, pp. 53-82.

Gerber, K., Giblin-Davis, R.M. \& Escobar-Goyes, J. (1990). Association of the red ring nematode, Rhadinaphelenchus cocophilus, with weevils from Ecuador and Trinidad. Journal of Nematology 22, 143-149.

Giblin-Davis, R., Mundo-Ocampo, M., Baldwin, J., Gerber, K. \& Griffith, R. (1989). Observations on the morphology of the red ring nematode, Rhadinaphelenchus cocophilus (Nemata: Aphelenchoididae). Revue de Nématologie 12, 285-292. 
Giblin-Davis, R.M., Kanzaki, N., Ye, W., Center, B.J. \& Thomas, W.K. (2006). Morphology and systematics of Bursaphelenchus gerberae n. sp. (Nematoda: Parasitaphelenchidae), a rare associate of the palm weevil, Rhynchophorus palmarum in Trinidad. Zootaxa 1189, 39-53.

Giblin-Davis, R.M., Kanzaki, N. \& Davies, K.A. (2013). Nematodes that ride insects: unforeseen consequences of arriving species. Florida Entomologist 96, 770-780.

Griffith, R. (1968). The relationship between the red ring nematode and the palm weevil. Journal of Agricultural Society of Trinidad and Tobago 68, 342-356.

Jung, J., Han, H., Ryu, S. \& Kim, W. (2010). Microsatellite variation in the pinewood nematode, Bursaphelenchus xylophilus (Steiner and Buhrer) Nickle in South Korea. Genes \& Genomics 32, 151-158.

Kanzaki, N. \& Giblin-Davis, R.M. (2012). Aphelenchoidea. In: Manzanilla-López, R.H. \& Márban-Mendoza, N. (Eds). Practical plant nematology. Mexico City, Mexico, Mundi Prensa-CP, pp. 161-208.

Kanzaki, N., Tanaka, R., Giblin-Davis, R.M. \& Davies, K. (2014). New plant-parasitic nematode from the mostly mycophagous genus Bursaphelenchus discovered inside figs in Japan. PLoS ONE 9, e99241.

Kaplan, D.T., Thomas, W.K., Frisse, L.M., Sarah, J.L., Stanton, J.M., Speijer, P.R., Marin, D.H. \& Opperman, C.H. (2000). Phylogenetic analysis of geographically diverse Radopholus similis via rDNA sequence reveals a monomorphic motif. Journal of Nematology 32, 134-142.

Katoh, K. \& Standley, M. (2013). MAFFT Multiple Sequence Alignment Software version 7: improvements in performance and usability. Molecular Biology and Evolution 30, 772-780.

Larget, B. \& Simon, D. (1999). Markov chain Monte Carlo algorithms for the Bayesian analysis of phylogenetic trees. Molecular Biology and Evolution 16, 750-759.

Li, H., Trinh, P., Waeyenberge, L. \& Moens, M. (2009). Characterisation of Bursaphelenchus spp. isolated from packaging wood imported at Nanjing, China. Nematology 11, 375-408.

Marek, M., Zouhar, M., Douda, O., Gaar, V. \& Ryšánek, P. (2014). Comparative molecular analysis of Bursaphelenchus vallesianus, a wood-inhabiting nematode isolated from declining pine trees in the Czech Republic. Plant Pathology 63, 232-242.

Mekete, T., Reynolds, K., Lopez-Nicora, H.D., Gray, M.E. \& Niblack, T.L. (2011). Distribution and diversity of rootlession nematode (Pratylenchus spp.) associated with Miscanthus $\times$ giganteus and Panicum virgatum used for biofuels, and species identification in a multiplex polymerase chain reaction. Nematology 13, 673-686.

Mota, M. \& Vieira, P. (Eds) (2008). Pine wilt disease: a worldwide threat to forest ecosystems. Dordrecht, The Netherlands, Springer.

Mota, M.M., Takemoto, S., Takeuchi, Y., Hara, N. \& Futai, K. (2006). Comparative studies between Portuguese and
Japanese isolates of the pinewood nematode, Bursaphelenchus xylophilus. Journal of Nematology 38, 429-433.

Múnera Uribe, G.E., Bert, W., Vierstraete, A., de la Peña, E., Moens, M. \& Decraemer, W. (2010). Burrowing nematodes from Colombia and their relationship with Radopholus similis populations, $R$. arabocoffeae and $R$. duriophilus. Nematology $12,619-629$.

Nunn, G.B. (1992). Nematode molecular evolution: an investigation of evolutionary patterns among nematodes based upon DNA sequences. Ph.D. Thesis, University of Nottingham, Nottingham, UK.

Oliveira, C., Fentoni, B., Malloch, G., Brown, M. \& Nelson, R. (2005). Development of species-specific primers for the ectoparasitic nematode species Xiphinema brevicolle, $X$. diffusum, X. elongatum, X. ifacolum and X. longicaudatum (Nematoda: Longidoridae) based on ribosomal DNA sequences. Annals of Applied Biology 146, 281-288.

Oliveira, C., Eulálio, J., Bessi, R. \& Harakava, R. (2011). Caracterizações morfológica e molecular de Bursaphelenchus fungivorus (Nematoda: Aphelenchida), detectado pela primeira vez no Brasil. Nematologia Brasileira 35, 63-70.

Palomares-Rius, J., Landa, B., Maafi, Z., Hunt, D.J. \& Castillo, P. (2010). Comparative morphometrics and ribosomal DNA sequence analysis of Longidorus orientalis Loof, 1983 (Nematoda: Longidoridae) from Spain and Iran. Nematology 12, 631-640.

Palomares-Rius, J.E., Cantalapiedra-Navarrete, C., GutiérrezGutiérrez, C., Liébanas, G. \& Castillo, P. (2013). Morphological and molecular characterisation of Paralongidorus plesioepimikis n. sp. (Nematoda: Longidoridae) from southern Spain. Nematology 15, 363-378.

Pereira, F., Moreira, C., Fonseca, L., Van Asch, B., Mota, M., Abrantes, I. \& Amorim, A. (2013). New insights into the phylogeny and worldwide dispersion of two closely related nematode species, Bursaphelenchus xylophilus and Bursaphelenchus mucronatus. PLoS ONE 8, e56288.

Rambaut, A. (2008). FigTree v1.4.2: tree figure drawing tool. Available online at http://tree.bio.ed.ac.uk/software/figtree/ (accessed 13 January 2016).

Rambaut, A. \& Drummond, A.J. (2007). Tracer v1.4: MCMC trace analyses tool. Available online at http://beast.bio.ed.ac. uk/Tracer (accessed 13 January 2016).

Ronquist, F. \& Huelsenbeck, J.P. (2003). MRBAYES 3: Bayesian phylogenetic inference under mixed models. Bioinformatics 19, 1572-1574.

Rozen, S. \& Skaletsky, H.J. (1999). Primer3 on the WWW for general users and for biologist programmers. In: Misener, S. \& Krawetz, S.A. (Eds). Methods in molecular biology, 132. Bioinformatics methods and protocols. Totowa, NJ, USA, Springer, pp. 365-386.

Saeki, Y., Kawanoa, E., Yamashita, C., Akaoa, S. \& Nagatomoa, Y. (2003). Detection of plant parasitic nematodes, Meloidogyne incognita and Pratylenchus coffeae by multiplex PCR 
using specific primers. Soil Science and Plant Nutrition 49, 291-295.

Silva, H.M. (1991). Metamasius sp. (Coleoptera, Curculionidae) vetor do Rhadinaphelenchus cocophilus agente causador do anel vermelho do dendezeiro. EMBRAPA Amazônia Oriental - Séries Anteriores. INFOTECA-E, pp. 1-4.

Singh, S.K., Hodda, M., Ash, G.J. \& Banks, N.C. (2013). Plant-parasitic nematodes as invasive species: characteristics, uncertainty and biosecurity implications. Annals of Applied Biology 163, 323-350.

Subbotin, S.A., Cid del Vera, I., Mundo-Ocampo, M. \& Baldwin, J.G. (2011). Identification, phylogeny and phylogeography of circumfenestrate cyst nematodes (Nematoda: Heteroderidae) as inferred from analysis of ITS-rDNA. Nematology $13,805-824$.

Sultana, T., Han, H. \& Park, J. (2013). Comparison of complete mitochondrial genomes of pine wilt nematode Bursaphelenchus xylophilus and Bursaphelenchus mucronatus (Nematoda: Aphelenchoidea) and development of a molecular tool for species identification. Gene 520, 39-46.

Takeuchi, Y., Kanzaki, N. \& Futai, K. (2005). A nested PCRbased method for detecting the pine wood nematode, Bursaphelenchus xylophilus, from pine wood. Nematology 7, 775782.

Tamura, K., Peterson, D., Peterson, N., Stecher, G., Nei, M. \& Kumar, S. (2011). MEGA5: molecular evolutionary genetics analysis using maximum likelihood, evolutionary distance, and maximum parsimony methods. Molecular Biology and Evolution 28, 2731-2739.

Tanabe, K.S. (2011). Kakusan4 and Aminosan: two programs for comparing nonpartitioned, proportional and separate models for combined molecular phylogenetic analyses of multilocus sequence data. Molecular Ecology Resources 11, 914921.

Tanaka, S.E., Tanaka, R., Akiba, M., Aikawa, T., Maehara, N., Takeuchi, Y. \& Kanzaki, N. (2014). Bursaphelenchus niphades n. sp. (Tylenchina: Aphelenchoididae) amensally associated with Niphades variegatus (Roelofs) (Coleoptera: Curculionidae). Nematology 16, 259-281.

Valadas, V., Laranjo, M., Barbosa, P., Espada, M., Mota, M. \& Oliveira, S. (2012). The pine wood nematode, Bursaphelenchus xylophilus, in Portugal: possible introductions and spread routes of a serious biological invasion revealed by molecular methods. Nematology 14, 899-911.

Valadas, V., Laranjo, M., Mota, M. \& Oliveira, S. (2013). Molecular characterization of Portuguese populations of the pinewood nematode Bursaphelenchus xylophilus using cytochrome b and cellulase genes. Journal of Helminthology 87 , 457-466.

Van Ghelder, C., Reid, A., Kenyon, D. \& Esmenjaud, D. (2015). Development of a real-time PCR method for the detection of the dagger nematodes Xiphinema index, $X$. diversicaudatum, $X$. vuittenezi and $X$. italiae, and for the quantification of $X$. index numbers. Plant Pathology 64, 489-500.

Vicente, C., Espada, M., Vieira, P. \& Mota, M. (2012). Pine wilt disease: a threat to European forestry. European Journal of Plant Pathology 133, 89-99.

Vossen, J.H., Jo, K.R. \& Vosman, B.J. (2014). Mining the genus Solanum for increasing disease resistance. In: Tuberosa, R., Graner, A. \& Frison, E. (Eds). Genomics of plant genetic resources. Dordrecht, The Netherlands, Springer, pp. 27-46.

Vrain, T.C. (1993). Restriction fragment length polymorphism separates species of the Xiphinema americanum group. Journal of Nematology 25, 361-364.

Ye, W. \& Giblin-Davis, R.M. (2013). Molecular characterization and development of real-time PCR assay for pine-wood nematode Bursaphelenchus xylophilus (Nematoda: Parasitaphelenchidae). PLoS ONE 8, e78804.

Ye, W., Giblin-Davis, R.M., Braasch, H., Morris, K. \& Thomas, W.K. (2007). Phylogenetic relationships among Bursaphelenchus species (Nematoda: Parasitaphelenchidae) inferred from nuclear ribosomal and mitochondrial DNA sequence data. Molecular Phylogenetics and Evolution 43, 1185-1197.

Yoder, M., De Ley, I., King, I., Mundo-Ocampo, M., Mann, J., Blaxter, M., Poiras, L. \& De Ley, P. (2006). DESS: a versatile solution for preserving morphology and extractable DNA of nematodes. Nematology 8, 367-376.

Zhang, K., Liu, H., Sun, J., Liu, J., Fei, K., Zhang, C., Xu, M., Sun, J., Ma, X., Lai, R. et al. (2008). Molecular phylogeny of geographical isolates of Bursaphelenchus xylophilus: implications on the origin and spread of this species in China and worldwide. Journal of Nematology 40, 127-137.

Zhou, Z., Daisuke, S., Wu, B. \& Hogetsu, T. (2007). Genetic structure of populations of the pinewood nematode Bursaphelenchus xylophilus, the pathogen of pine wilt disease, between and within pine forests. Phytopathology 97, 304-310.

Zijlstra, C. (1997). A fast PCR assay to identify Meloidogyne hapla, M. chitwoodi and M. fallax, and to sensitively differentiate them from each other and from $M$. incognita in mixtures. Fundamental and Applied Nematology 20, 505-511. 